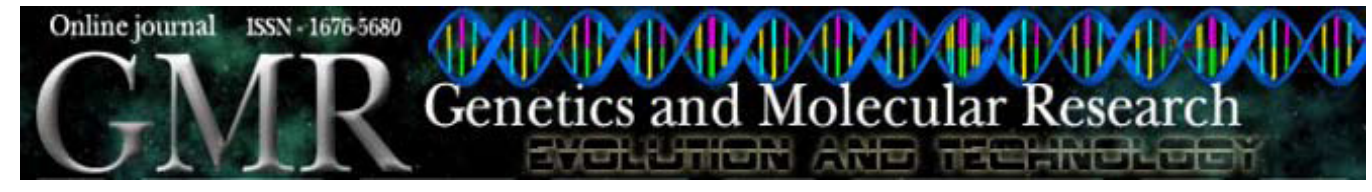

\title{
Evidence of ecotypic differentiation between populations of the tree species Parapiptadenia rigida due to flooding
}

\author{
D.C.G. Silva ${ }^{1}$, M.C.C.G. Carvalho' ${ }^{2}$ P.M. Ruas ${ }^{3}$, C.F. Ruas ${ }^{3}$ and \\ M.E. Medri ${ }^{4}$ \\ ${ }^{1}$ Departamento de Biologia e Tecnologia, \\ Universidade Estadual do Norte do Paraná, \\ Campus Luiz Meneghel, Bandeirantes, PR, Brasil \\ ${ }^{2}$ Departamento de Ciências Biológicas, \\ Universidade Estadual Paulista, Assis, SP, Brasil \\ ${ }^{3}$ Departamento de Biologia Geral, \\ Universidade Estadual de Londrina, Londrina, PR, Brasil \\ ${ }^{4}$ Departamento de Biologia Animal e Vegetal, \\ Universidade Estadual de Londrina, Londrina, PR, Brasil \\ Corresponding author: D.C.G. Silva \\ E-mail: daniellegregorio@ffalm.br
}

Genet. Mol. Res. 9 (2): 797-810 (2010)

Received January 11, 2010

Accepted February 8, 2010

Published May 4, 2010

DOI 10.4238/vol9-2gmr736

\begin{abstract}
The tree species Parapiptadenia rigida, native to southern South America, is frequently used in reforestation of riverbanks in Brazil. This tree is also a source of gums, tannins and essential oils, and it has some medicinal uses. We investigated flooding tolerance and genetic diversity in two populations of P. rigida; one of them was naturally exposed to flooding. Plants derived from seeds collected from each population were submitted to variable periods of experimental waterlogging and submergence. Waterlogging promoted a decrease in biomass and structural adjustments, such as superficial roots with aerenchyma and hypertrophied lenticels, that contribute to increase atmospheric oxygen intake. Plants that were submerged had an even greater reduction in biomass and a high mortality
\end{abstract}


rate $(40 \%)$. The two populations varied significantly in their RAPD marker profiles, in their ability to produce aerenchyma when waterlogged and to survive when submerged, suggesting ecotypic differentiation between them. Hence, the seasonal flooding that has been challenging the tropical riparian forest appears to be genetically modifying the $P$. rigida populations exposed to it by selecting individuals with increased ability to live under this condition.

Key words: Waterlogging; Submergence; Parapiptadenia rigida; Genetic diversity; RAPD; Local adaptation

\section{INTRODUCTION}

Flooding and subsequent submergence of vegetation in tropical rivers is a common phenomenon (Fernández, 2006). Flooding constitutes a limiting factor to plant growth and survival. This is largely due to reduced gas exchange between plants and the rhizosphere during partial submergence, leading to decline in molecular $\mathrm{O}_{2}$ and to restriction of ATP synthesis and carbohydrate resources (Kozlowsky, 1984; Bailey-Serres and Voesenek, 2008). Complete submergence has an even greater effect on plants and is therefore a stronger constraint. Totally submerged plants have no direct contact with atmospheric oxygen, and sunlight is weak or extinguished. Floodwaters have high levels of sediment deposition, which increases the severity of hypoxia and harms leaf photosynthesis below water by imposing turbidity and depositing sediments on the leaf surfaces; these remain after the floodwater recedes (Parolin, 2009).

In order to survive in an inundated environment with deep or ephemeral floods, some species use a tolerant quiescence strategy characterized by limited underwater growth and conservation of energy and carbohydrates. Other species use the low oxygen escape syndrome (LOES), an avoidance strategy that facilitates the survival of submerged organs through the development of anatomical and morphological traits (Bailey-Serres and Voesenek, 2008). Some of these traits are frequently developed by tree species living at the borders of tropical rivers. They include aerenchyma formation (Kolb et al., 1998; Medri et al., 2007), adventitious rooting (Kolb et al., 1998; Batista et al., 2008), superficial rooting (Kolb et al., 1998; Davanso et al., 2003), stem lenticel hypertrophy (Kolb et al., 1998; Santiago and Paoli, 2003; Medri et al., 1998, 2007; Batista et al., 2008), and the opening of fissures at the base of the stems (Davanso et al., 2003). These traits facilitate inward diffusion of $\mathrm{CO}_{2}$ and $\mathrm{O}_{2}$ and reduce resistance against internal gas diffusion, thereby improving underwater photosynthesis and aerobic metabolism. LOES can also lead to increased elongation of petioles, stems, and leaves upon complete submergence, restoring the contact between leaves and air (Bailey-Serres and Voesenek, 2008).

Differences in inundation intensity in populations distributed in a gradient of soil humidity at river margins can provoke intraspecific variation in flooding tolerance. Some studies have indicated genetic variation within species in morphological and physiological traits involved in the plants' ability to cope with flooding stress (Chan and Burton, 1992; Lenssen et al., 2004; Ferreira et al., 2007; De Carvalho et al., 2008). Flooding episodes could select genotypes more adapted to tolerate or avoid this stress, resulting in increased genetic diversity between populations and local adaptation. However, genetic differentiation in physiological and morphological traits can only be attributed to local adaptation if there is also differentia- 
tion in fitness responses to flooding and if the effects of these traits on fitness differ between flooding environments (Lenssen et al., 2004). Unfortunately, it is hard to estimate fitness in arboreal species, mainly because of their long life cycles. Nevertheless, differences in survival ability due to different genotypes can quickly change allele frequencies in a population, indicating a potential for selection.

Parapiptadenia rigida is a tree species that is widely spread throughout the Atlantic forest in Brazil, Paraguay, Uruguay, and Argentina, and it is frequently used in reforestation programs of riparian forests due to its ability to support flooding stress. This species is distributed both in low-elevation riverside habitats, where it faces flooding episodes, and in highelevation habitats. We investigated the strategy used by this species to live along river borders and the role of flooding and submergence in selecting $P$. rigida genotypes more adapted to handle this condition. We addressed the following questions in this study: a) Does $P$. rigida develop morphological, anatomical and growing adjustments to cope with flooding and submergence? b) Can intensified inundation affect the survival of this species? c) Is there sufficient genetic diversity between populations to indicate different genotypes in these populations? If so, d) Are there differences in morphological traits, growing and survival ability between populations that demonstrate a potential for inundation selection acting on this species?

\section{MATERIAL AND METHODS}

\section{Study species}

Parapiptadenia rigida Benth. Brennan (Mimosaceae) is a pioneer tree commonly known in Brazil as "angico-vermelho" and "gurucaia". Gum, essential oils, and tannin are extracted from this tree; the latter two have medicinal uses. The wood is dense and resistant to the elements and termites, being frequently used in construction. This species is open pollinated, blooming from November to December, and seed pods ripen mainly between July and August of the following year (Lorenzi, 1992).

\section{Study area}

The study area is a fragment of riparian forest alongside Tibagi River, in the State

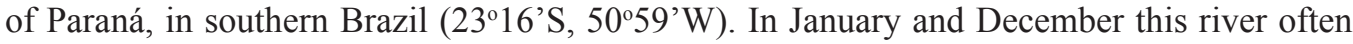
overflows. At this time, young plants of $P$. rigida are 4 to 7 months old and face periods of soil flooding and submersion. Given the topography of the study area, plants located at low elevation riverside areas are frequently exposed to inundation, whereas plants located nearby high elevation areas are not exposed to inundation. This allowed us to divide a $\sim 600 \times 250-\mathrm{m}$ area, occupied by adult individuals, into two populations: naturally exposed and unexposed to inundation. Forty-four individuals having mature fruit, 22 from each population, were selected for the study. They were sampled for seeds and leaves.

\section{Plant material}

Seeds from the two populations were germinated in plastic tubes with $700 \mathrm{~g}$ wet substratum ( $80 \%$ soil; $20 \%$ mixture of grated grass, lime and coffee powder) in a nursery. Two months 
later, the plants were transferred to 4-L plastic pots with soil and sand (3:1, respectively) and left to grow and acclimate for 2 months in a greenhouse $\left(25^{\circ} \mathrm{C}, 80 \%\right.$ moisture, $14 \mathrm{~h}$ of sunlight $)$. After acclimation, young plants from both populations were subjected to the following conditions: drained (D), flooded (F), and submerged (S). Drained conditions were obtained by watering the plants once a day in order to keep the soil humid. Flooded conditions were achieved by sealing the pots to avoid water leakage and watering them twice a day in order to keep the water level 5 $\mathrm{cm}$ above the soil surface. For the submersion condition, pots with plants were totally submerged in a container filled with running water. These conditions were maintained for different time spans, as explained below. In each analysis, each trial contained 20 plants, 10 from the population naturally exposed to inundation, and 10 from the population unexposed to inundation.

\section{Anatomy analysis}

To test the ability of the two populations to adapt anatomically when inundated, young plants were kept for 30 days under two conditions: D or F (Figure 1). A previous experiment showed that the submergence condition does not significantly change the internal structure of the existing roots and the stem of $P$. rigida (Medri ME, unpublished results); it does not induce the development of new roots either, so this condition was not applied to this analysis. Transverse sections of new secondary roots and longitudinal segments of the base of the stems were cut 10$12 \mu \mathrm{m}$ thick with a microtome and stained with astra blue and basic fuchsin. The radius of the central cylinder, cortex thickness, diameter and number of cortical cell layers, and cortical porosity were evaluated in roots and stems. The porosity was analyzed as follows. Images of $10 \mathrm{sec}-$ tions of each plant were reproduced using a microscope adapted to a tube for image projection (Zeiss 451465). Photomicroscope images were 200-fold enlarged, allowing individualization of cells and intercellular spaces. The images printed on uniform paper $\left(75 \mathrm{~g} / \mathrm{m}^{2}\right)$ were divided into sections representing cells and sections representing intercellular spaces. The dry weight of the two parts was used for the calculation of intercellular space percentage (porosity).

\section{Growth analysis}

The ability of young plants to grow under inundation was tested by comparing the dry mass of individuals grown for 30 days under the three conditions: D, F and S (Figure 1). Initial biomass was recorded prior to the flooding experiment and was used in the calculation of the relative growth rate (RGR). RGR was measured as the change in dry weight using the formula: $R G R=1000 \times\left[\ln \left(D^{2} t_{0}\right)-\ln \left(D_{W t}\right)\right] /\left(t_{0}-t_{1}\right) m g /$ day, where DW is the dry weight of the component at time $t$.

\section{Morphology and survival analyses}

To investigate the effects of different regimens of inundation on the external morphology and the survival capability of plants from the two populations, individuals were kept for 30 days under one of three conditions: D, F, or S (Figure 1). Natural inundation periods in the study area are typically shorter than 30 days. We also conducted inundation treatments for 60 days: continuously drained (DD), flooded for 30 days, followed by drained for an additional 30 days (FD), flooded for 30 days, followed by submerged for an additional 30 days (FS), and continu- 
ously flooded (FF) (Figure 1). The FS condition simulates an intensification of flooding during the inundation period, resulting in the submergence of young plants, while FD simulates a situation where flooding begins and then stops. The re-aeration of flooded soil was accomplished by unsealing the pots and allowing the soil to return naturally to a drained condition. As there was no previous information on the responses of tree species to submersion, because of local observations of tolerance of $P$. rigida to this type of stress, and because the analyses performed in all treatments were destructive, we added a 30-day re-aeration period to the FS test, consequently testing the ability of the trees to recover from this injury. The treatments sustained for 90 days were: continuously drained (DDD), and flooding for 30 days, followed by submerged for an additional 30 days, followed by draining for a further 30 days (FSD) (Figure 1).

The length of roots and stems, diameter at the base of stem, percentage foliar abscission, and number of hypertrophied lenticels, adventitious roots, superficial roots, and new leaves were evaluated in this essay.

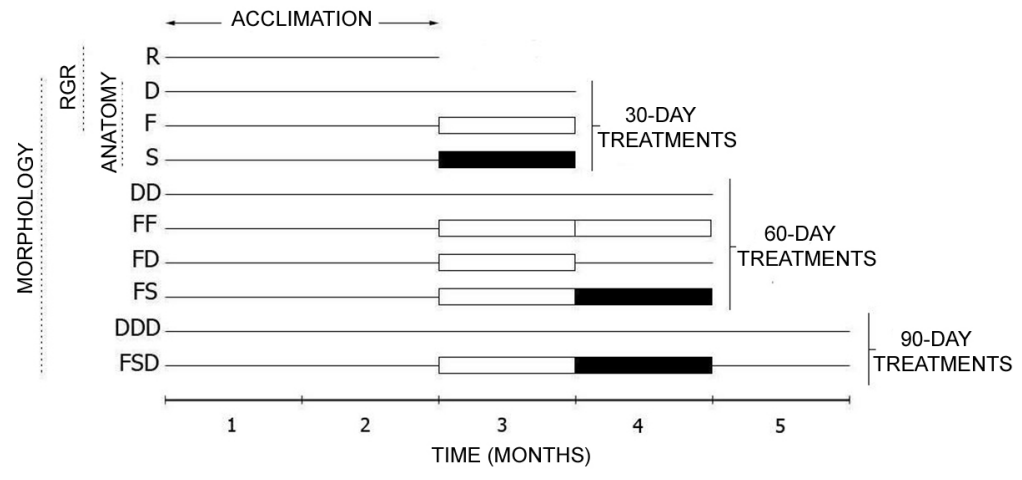

Figure 1. Experimental design of treatments comparing flooding tolerance between the two populations of Parapiptadenia rigida (exposed and unexposed to flooding). Horizontal lines indicate draining condition, open bars indicate the flooding condition, and filled bars indicate the submergence condition. In each treatment, an initial horizontal line represents the 2-month acclimation period. 30-day treatments $=\mathrm{R}$ (reference of initial biomass for the calculation of RGR), D (draining), F (flooding), and S (submerged); 60-day treatments = DD (continuous draining), FF (continuous flooding), FD (30 days on flooding +30 days on draining), FS (30 days on flooding +30 days on submergence), and 90-day treatments $=$ DDD (continuous draining), and FSD (30 days flooding +30 days submergence +30 days draining). The types of analyses performed for each treatment are shown on the left. RGR $=$ relative growth rate.

\section{Genetic analysis}

Total DNA of young leaves of 22 individuals from each population (exposed and unexposed to inundation) was isolated following the method described by Doyle and Doyle (1987). DNA concentration was estimated using a fluorometer (DyNA Quant 200, Höefer-Pharmacia), according to manufacturer instructions. Polymerase chain reactions (PCR) and DNA amplification were performed using the parameters described in Silveira et al. (2003). Fragments generated by amplification were separated on 1.4\% agarose gels in 1X TAE ( $40 \mathrm{mM}$ Tris-acetate, $1 \mathrm{mM}$ EDTA, pH 8.0) buffer, stained with ethidium bromide, visualized under UV light, and photographed using a video camera (Cohu, High Performance CCD Camera). Eighty random amplified polymorphic DNA (RAPD) primers (Operon Technologies) were tested for polymorphism. 
Amplification products were scored as binary characters (present/absent). Since $P$. rigida is a cross-pollinated species, it is assumed that genotype information could be missing due to the dominance of RAPDs, consequently causing a biased estimation of null-allele frequency when the null homozygotes are rare within populations (Lynch and Milligan, 1994). To minimize this problem, two sets of data were submitted to analysis: a) the total number of markers and $b$ ) the markers with frequencies lower than $1-[3 / N]$, where $\mathrm{N}$ is the number of sampled plants, as suggested by Lynch and Milligan (1994).

\section{Statistical analysis}

Analysis of variance (ANOVA) and the Tukey test, at 5\% significance, were applied to growth, anatomy and morphology data using the System of Statistical Analysis (SAS, 1990) program. For morphology data, the statistical analysis was run on the three sets of treatments: 30, 60, and 90 days.

Analysis of molecular variance (AMOVA, Excoffier et al., 1992), defined for RAPDs by Huff et al. (1993), was applied to estimate the distribution of genetic variation within and between populations through the $\phi$-statistic, using the Arlequin v. 1.1 software (Schneider et al., 1997).

\section{RESULTS}

Parapiptadenia rigida saplings exposed to flooding had no alterations in stem anatomy, but root anatomy was strongly affected (Table 1). Flooding caused a decrease in the radius of the root central cylinder and an increase in the thickness of the cortex (Table 1). Both, the number of cortical cell layers and the diameter of cortical cells rose significantly after flooding, increasing root cortical porosity (Table 1, Figure 2). Aerenchyma, identified in the uppermost of recently formed secondary roots, did not show cellular residues. Root anatomy also changed differently in the populations after flooding. The thickness of the cortex, diameter of cortical cells and cortical porosity were higher in plants from the population naturally exposed to inundation (Table 2). This was the first result indicating an inherent difference between the populations.

Biomass increment in $P$. rigida young trees was significantly affected by flooding and submergence. In all parts of the plants, roots, stems and leaves, relative growth rate decreased during submergence (Table 1). The length of $P$. rigida roots and stems decreased under flooding and submergence (Table 1). The reduction in the length of the stem was more pronounced when plants were subjected to 30 days of submergence than to 30 days of flooding (Table 1). Re-aeration, accomplished in FD, stimulated the recovery of root length (Table 1). The diameter at the base of the stem reached the highest values under treatments involving flooding, and the lowest values under some of the treatments involving submergence, including S and FSD (Table 1). Submergence in the S, FS, and FSD treatments caused foliar abscission in $P$. rigida plants, whereas flooding (F, FF, and FD) did not affect this parameter (Table 1). Conversely, hypertrophied lenticels were markedly induced on the third day following the onset of flooding (F, FF, and FD; Table 1). Generally, the hypertrophied lenticels were relatively unindividualized, forming masses of spongy tissue around the stem base (Figure 3). The fragility of this tissue, combined with higher volume, and consequently higher water pressure during the 30-day submergence periods in the FS and FSD treatments led to loss of hypertrophied lenticels (Table 1). 


\begin{tabular}{|c|c|c|c|c|c|c|c|c|c|c|}
\hline Analysis & Parameters & $\mathrm{D}$ & F & $\mathrm{S}$ & $\mathrm{DD}$ & $\mathrm{FF}$ & FD & FS & DDD & FSD \\
\hline \multirow[t]{4}{*}{ Growth } & Root RGR (mg/day) & $25.24^{\mathrm{a}}$ & $10.44^{\mathrm{b}}$ & $-0.65^{\mathrm{c}}$ & - & - & - & - & - & - \\
\hline & Stem RGR (mg/day) & $27.26^{\mathrm{a}}$ & $26.48^{\mathrm{a}}$ & $-2.97^{\mathrm{b}}$ & - & - & - & - & - & - \\
\hline & Leaf RGR (mg/day) & $25.05^{\mathrm{a}}$ & $16.38^{\mathrm{b}}$ & $-19.72^{c}$ & - & - & - & - & - & - \\
\hline & Total RGR (mg/day) & $25.75^{\mathrm{a}}$ & $18.32^{\mathrm{b}}$ & $-19.68^{c}$ & - & - & - & - & - & - \\
\hline \multirow[t]{10}{*}{ Anatomy } & Radius of the stem central cylinder $(\mu \mathrm{m})$ & $142.47^{\mathrm{a}}$ & $131.84^{\mathrm{a}}$ & - & - & - & - & - & - & - \\
\hline & Thickness of stem cortex $(\mu \mathrm{m})$ & $202.03^{\mathrm{a}}$ & $183.76^{\mathrm{a}}$ & - & - & - & - & - & - & - \\
\hline & Number of cortical cell layers in the stem $(\mathrm{N})$ & $26.19^{\mathrm{a}}$ & $31.56^{\mathrm{a}}$ & - & - & - & - & - & - & - \\
\hline & Diameter of the stem cortical cells $(\mu \mathrm{m})$ & $20.13^{\mathrm{a}}$ & $17.39^{\mathrm{a}}$ & - & - & - & - & - & - & - \\
\hline & Stem porosity $(\%)$ & $4^{\mathrm{a}}$ & $4.2^{\mathrm{a}}$ & - & - & - & - & - & - & - \\
\hline & Radius the root central cylinder $(\mu \mathrm{m})$ & $116.12^{\mathrm{a}}$ & $84.77^{\mathrm{b}}$ & - & - & - & - & - & - & - \\
\hline & Thickness of root cortex $(\mu \mathrm{m})$ & $107.26^{\mathrm{b}}$ & $199.15^{\mathrm{a}}$ & - & - & - & - & - & - & - \\
\hline & Number of cortical cell layers in the $\operatorname{root}(\mathrm{N})$ & $7.76^{\mathrm{b}}$ & $10.13^{\mathrm{a}}$ & - & - & - & - & - & - & - \\
\hline & Diameter of root cortical cells $(\mu \mathrm{m})$ & $20.06^{\mathrm{b}}$ & $26.94^{\mathrm{a}}$ & - & - & - & - & - & - & - \\
\hline & Root porosity (\%) & $4.95^{\mathrm{b}}$ & $8.26^{\mathrm{a}}$ & - & - & - & - & - & - & - \\
\hline \multirow[t]{8}{*}{ Morphology } & Root length $(\mathrm{cm})$ & $53.6^{\mathrm{a}}$ & $32.0^{\mathrm{b}}$ & $26.1^{\mathrm{b}}$ & $46.70^{\mathrm{A}}$ & $33.43^{\mathrm{C}}$ & $39.15^{\mathrm{B}}$ & $30.43^{\mathrm{C}}$ & $50.81^{a}$ & $34.83^{b}$ \\
\hline & Stem length $(\mathrm{cm})$ & $42.4^{\mathrm{a}}$ & $33.9^{\mathrm{b}}$ & $25.5^{\mathrm{c}}$ & $69.3^{\mathrm{A}}$ & $41.18^{\mathrm{B}}$ & $41.98^{\mathrm{B}}$ & $40.43^{\mathrm{B}}$ & $64.70^{a}$ & $44.57^{b}$ \\
\hline & Diameter at the base of stem $(\mathrm{cm})$ & $0.47^{\mathrm{b}}$ & $0.97^{\mathrm{a}}$ & $0.36^{\mathrm{c}}$ & $0.59^{\mathrm{B}}$ & $1.81^{\mathrm{A}}$ & $1.57^{\wedge}$ & $0.71^{\mathrm{B}}$ & $1.73^{a}$ & $1.08^{b}$ \\
\hline & Foliar abscission (\%) & $12.3^{\mathrm{b}}$ & $11.9^{\mathrm{b}}$ & $32.3^{\mathrm{a}}$ & $17.7^{\mathrm{B}}$ & $24.5^{\mathrm{B}}$ & $18.6^{\mathrm{B}}$ & $100^{\mathrm{A}}$ & $32.4^{b}$ & $100^{a}$ \\
\hline & Hypertrophied lenticels (N) & $0^{\mathrm{b}}$ & $101.1^{\mathrm{a}}$ & $0^{\mathrm{b}}$ & $0^{\mathrm{c}}$ & $150.60^{\AA}$ & $116.26^{\mathrm{B}}$ & $0^{\mathrm{c}}$ & $0^{a}$ & $0^{a}$ \\
\hline & Adventitious roots $(\mathrm{N})$ & $0^{\mathrm{a}}$ & $0^{\mathrm{a}}$ & $0^{\mathrm{a}}$ & $0^{\mathrm{B}}$ & $0.3^{\mathrm{A}}$ & $0^{\mathrm{B}}$ & $0^{\mathrm{B}}$ & $0^{a}$ & $0^{a}$ \\
\hline & Superficial roots $(\mathrm{N})$ & $0^{\mathrm{b}}$ & $0.41^{\mathrm{a}}$ & $0^{\mathrm{b}}$ & $0^{\mathrm{B}}$ & $4.87^{\mathrm{A}}$ & $0^{\mathrm{B}}$ & 0 & $0^{a}$ & $0^{a}$ \\
\hline & New leaves $(\mathrm{N})$ & $2.58^{\mathrm{a}}$ & $1.96^{\mathrm{b}}$ & $0^{c}$ & $6.03^{\mathrm{A}}$ & $3.5^{\mathrm{B}}$ & $3.35^{\text {в }}$ & $0^{\mathrm{C}}$ & $8.57^{a}$ & $5.1^{b}$ \\
\hline
\end{tabular}

30-day treatments $=\mathrm{D}$ (draining), $\mathrm{F}$ (flooding), S (submerged); 60-day treatments = DD (continuous draining), FD (30 days flooding +30 days draining), FS (30 days flooding +30 days submerged), FF (continuous flooding); 90day treatments $=$ DDD (continuous draining), and FSD (30 days flooding +30 days submerged +30 days draining). Means with different letters are significantly different according to the Tukey test $(\mathrm{P} \leq 0.05)$. Lowercase letters compare means of the 30-day treatments, uppercase letters compare means of 60-day treatments, and italic letters compare means of the 90 -day treatments. RGR = relative growth rate. Foliar abscission was $100 \%$ in FS. Thus, all leaves in FSD were considered new leaves.

Table 2. Anatomical and morphological parameters showing significant differences between populations exposed and unexposed to flooding.

\begin{tabular}{llrr}
\hline Analysis & Parameters & \multicolumn{2}{c}{ Population } \\
\cline { 3 - 4 } & & Exposed to flooding & Unexposed to flooding \\
\hline Anatomy & Root porosity (\%) & $7.89^{\mathrm{a}}$ & $5.31^{\mathrm{b}}$ \\
& Diameter of root cortical cells $(\mu \mathrm{m})$ & $25.27^{\mathrm{a}}$ & $21.53^{\mathrm{b}}$ \\
& Thickness of the cortex $(\mu \mathrm{m})$ & $169.88^{\mathrm{a}}$ & $134.68^{\mathrm{b}}$ \\
Morphology & Number of new leaves $(\mathrm{N})$ & $1.6^{\mathrm{b}}$ & $8.7^{\mathrm{a}}$ \\
(90-day treatments) & Survivorship (\%) & $5 \%^{\mathrm{a}}$ & $1 \%^{\mathrm{b}}$ \\
\hline
\end{tabular}

Means with different letters are significantly different according to the Tukey test $(\mathrm{P} \leq 0.05)$.

Adventitious rooting was poorly developed by P. rigida plants. Only the intensified flooding condition (FF) induced the development of these roots from the non-waterlogged part of the stem (Table 1). A few superficial roots were observed after 30 days of flooding (F), and several of them were developed after intense flooding (FF; Table 1). These secondary roots were distributed above the soil, close to the water surface, and they were thicker than the adventitious roots (Figure 3). 


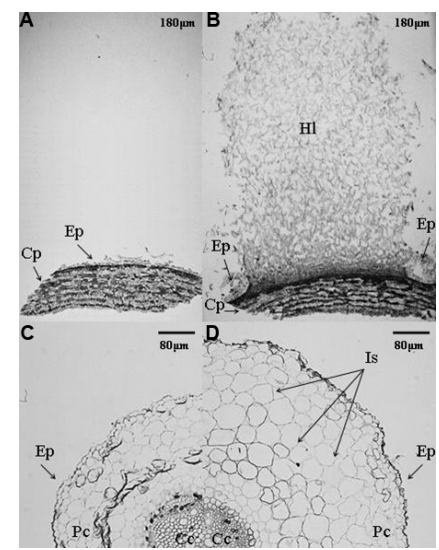

Figure 2. Anatomy of stem base and root segments of Parapiptadenia rigida saplings grown under flooding conditions. A. Cortex and epidermis of a plant grown under draining conditions for 30 days (D treatment). B. Cortex and epidermis of a plant grown under flooding conditions for 30 days (F treatment), evidencing lenticel hypertrophy. C. Root section of a plant grown under draining conditions for 30 days (D treatment). D. Root section of a plant grown under flooding conditions for 30 days $(\mathrm{F}$ treatment). $\mathrm{Ep}=$ epidermis; $\mathrm{Cp}=$ cortical parenchyma; $\mathrm{Hl}=$ hypertrophied lenticel; $\mathrm{Cc}=$ central cylinder; Is = intercellular space.

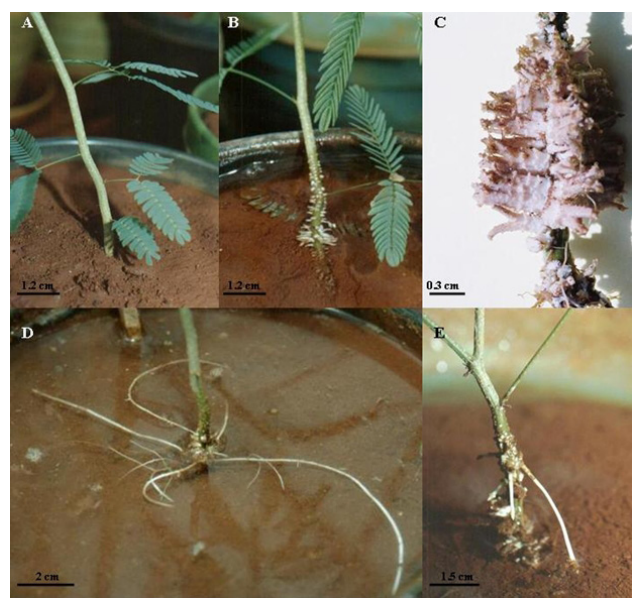

Figure 3. Morphology of Parapiptadenia rigida saplings developed under varying intensities of flooding and submergence. A. Plant grown under draining conditions for 30 days (D treatment). B. Plant grown under flooding conditions for 30 days (F treatment), showing hypertrophied lenticels. C. Hypertrophied lenticels of a plant grown under F treatment. D. Plant grown under flooding for 60 days (FF treatment), showing superficial roots. E. Stem base of a plant grown under FF treatment, showing adventitious roots.

Flooding and submergence had considerable influence on the growth of new leaves. Flooding in the F, FF, and FD treatments led to significant reductions in the number of new leaves (Table 1). Submergence reduced the production of leaves (Table 1). Indeed, the FS treatment injured $P$. rigida plants, resulting in thin, non-suberized, apparently lifeless stems, with no leaves and a damaged root system. However, the re-aeration period of 30 days, in the FSD treatment, induced resumption of leaf growth on $60 \%$ of the plants; the remaining $40 \%$ died (Figure 
4). Among the recovered plants, $50 \%$ were from the population naturally exposed to flooding, while only $10 \%$ were from the population unexposed to flooding, resulting in significant differences between the populations in the number of new leaves for plants in the 90-day treatments (Table 2). This was the clearest indication of an adaptive difference between the two populations.

Nineteen randomly selected RAPD primers were used in PCR. These primers generated 174 reproducible amplification products, with a mean of 9.16 markers per primer; 160 were polymorphic products. Among these amplified products, $23 \%$ exhibited frequencies between 0.863 and 1.0. These markers were eliminated from AMOVA, when the Lynch and Milligan (1994) criterion was followed. AMOVA applied to the total markers and to those within the range of frequencies suggested by Lynch and Milligan revealed the same pattern in the distribution of genetic variation. The $\phi_{\mathrm{st}}$ values for these two analyses were 0.0627 and 0.0509 , respectively, which demonstrates significant genetic diversity between populations (Table 3 ).

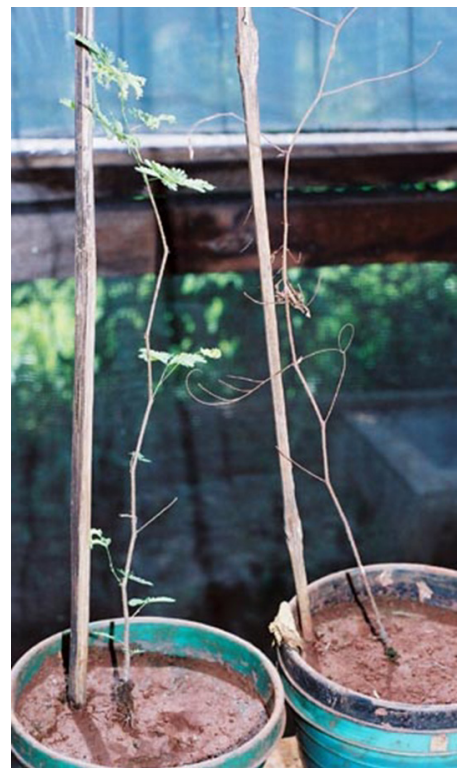

Figure 4. Morphology of Parapiptadenia rigida saplings developed under FSD treatment (30 days on flooding + 30 days on submergence +30 days on draining). Plant on the left, derived from the population exposed to flooding, recovered leaf growth during the re-aeration period of FSD. Plant on the right, derived from the population unexposed to flooding, did not recover leaf growth and died.

Table 3. Analysis of molecular variance (AMOVA) within and between the two populations of Parapiptadenia rigida (exposed and unexposed to flooding).

\begin{tabular}{lccccc}
\hline Analysis & Source of variation & d.f. & Sum of squares & C.V. & Variance \% \\
\hline Total markers & Between populations & 1 & 57.47 & 1.56 & $6.27 *$ \\
& Within population & 42 & 976.86 & 23.26 & 93.73 \\
L \& M & Between populations & 1 & 44.25 & 1.09 & $5.09 *$ \\
& Within population & 42 & 852.86 & 20.31 & 94.91 \\
\hline
\end{tabular}

The analysis is based on the total number of markers and on those markers that followed the Lynch and Milligan (1994) criterion $(\mathrm{L} \& \mathrm{M})$. d.f. $=$ degrees of freedom; C.V. $=$ coefficient of variation. ${ }^{*} \mathrm{P}<0.001$; levels of significance are based on 1023 permutations. 


\section{DISCUSSION}

\section{Responses to flooding and submergence}

It is widely recognized that some inundation-tolerant plants avoid low-oxygen stress by developing certain anatomical and morphological traits, in a strategy known as LOES (Bailey-Serres and Voesenek, 2008). P. rigida plants subjected to flooding developed hypertrophied lenticels, superficial and adventitious roots, and root aerenchyma (Table 2, Figures 2 and 3). Development of hypertrophied lenticels was the most prominent response of $P$. rigida to flooding (Figure 3). Given their prompt formation and the abundance of hypertrophied cortical tissue, this are believed to constitute an adaptation of this species to survive in the highly humid soil of river banks. The distribution of this character was uneven, suggesting that it has long been selected in this species. Hypertrophied lenticels are involved in gas exchange between the atmosphere and the intercellular spaces of stems and roots, providing a channel for elimination of metabolites produced by aerobic respiration (Tsukahara and Kozlowski, 1985). This character is frequently associated with flooding tolerance in tree species (Parolin, 2002; Kolb et al., 2002; Lopez and Kursar, 1999, 2003; Mielke et al., 2005).

The aerenchyma was developed in the root cortex of all $P$. rigida saplings subjected to flooding. Given the absence of cellular residues and the alterations observed in cell dimensions (Figure 2, Table 2), it is presumed to have a schizogenous origin. Aerenchyma facilitates gas transfer to the root system by lowering the resistance that hampers gas diffusion and mass flow within organs (Coutts and Armstrong, 1976; Bailey-Serres and Voesenek, 2008). As observed for hypertrophied lenticels, root porosity was uniformly distributed, suggesting that it is an ancient adaptation to survive in the riparian forest. Aerenchyma was detected in the recently formed secondary roots that developed from a region of the main root close to the water surface in the flooded pots. The higher oxygen concentration in this region combined with a system of interconnected channels could transport oxygen to the root tip. Although oxygenation of the rizhosphere was not experimentally tested, it is possible to assume that the aerenchyma is effective in providing gas transport through the roots, since anatomically the roots were healthy, even though they were partially submerged.

Flooding caused an increase in the base of the stem (Table 1), which is generally a consequence of aerenchyma formation in this organ (Yamamoto, 1992; Terazawa and Kikuzawa, 1994; Pimenta et al., 1996; Medri et al., 2002). However, for P. rigida, the diameter at the base of stem was enlarged as a result of lenticel hypertrophy, since there were no aerenchyma in the stem tissue, and the anatomical analyses showed no alterations in the thickness of cortex and central cylinder.

Adventitious and superficial roots were well developed in $P$. rigida under flooding, but not under submergence (Figure 3). This makes sense, since their advantage is their contact with atmospheric $\mathrm{O}_{2}$, which is difficult when the plant is completely submerged. Superficial and adventitial rooting occurred only under the intensified flooding condition (60 days), indicating that they are not among the primary adjustments of $P$. rigida to facilitate oxygen support to the root system. Furthermore, they were developed in only a few individuals, evidencing polymorphism in the population for this character. Although the importance of adventitious roots for the adaption of $P$. rigida to a riparian habitat is not clear, they are commonly observed in plant species as a consequence of flooding (Huang et al., 1997; Schmull and Thomas, 2000). However, superficial 
roots had been described for few tropical tree species (Davanso et al., 2003; Mano et al., 2006).

Flooding induced a significant decrease in biomass accumulation, in the number of new leaves, and in the length of roots and stems in the $P$. rigida saplings. The adjustments to submergence, however, were even more intense. Submerged plants not only suspended growth, but also shed all pre-existing leaves and lost part of the biomass of all components of the plant, leading to negative relative growth values. Growth reduction as a consequence of flooding and submergence is a common response of plants adapted to periodically waterlogged habitats (Steege, 1994; Pimenta et al., 1998; Davanso et al., 2002; Pisicchio, 2004; Batista et al., 2008; De Carvalho et al., 2008) and characterizes a latent state, resulting from changes in the hormonal and energetic balance in the plant. According to Bailey-Serres and Voesenek (2008), this quiescence strategy, driven by adjustment of metabolism, is a true tolerance mechanism. Respiration is downregulated and fermentation is limited to create a positive energy budget when organ hypoxia starts.

We conclude that $P$. rigida uses a combination of strategies in order to cope with different intensities of flooding. When flooding is shallow making the soil waterlogged and plants are only partially covered, an LOES strategy is favored, leading to an amelioration of oxygen supply to the tissues underwater, consequently ensuring survival of the plants. However, LOES is costly and its benefits do not outweigh the costs when the floods are too deep (Bailey-Serres and Voesenek, 2008) and the young plants are completely submerged. In these cases, the quiescence strategy is employed. Plants remain latent until the floodwater recedes, resulting in an economy of energy to be used in the later resumption of growth. Whether the LOES or the quiescence response to flooding is activated, cellular acclimation to transient $\mathrm{O}_{2}$ deprivation requires tight regulation of ATP production and consumption, limited acidification of the cytosol, and amelioration of reactive oxygen species produced either as $\mathrm{O}_{2}$ levels fall during flooding or upon reoxygenation after withdrawal of the flood water (Bailey-Serres and Voesenek, 2008).

Limited underwater growth and a consequent conservation of energy characterize an efficient adaptation to survive inundated habitats. Nonetheless, negative values in growth rates of $P$. rigida under submergence indicate not only a state of rest, but also injury to tissues and a threat to survival. Hence, for $P$. rigida, the quiescence strategy is harmful and some plants may not be able to recover after the end of this stress. This explains why $40 \%$ of the plants submitted to flooding for 30 days, submergence for 30 days and re-aeration for 30 days were not able to recover. Although the percentage survival was high (60\%), this shows that $P$. rigida suffers more under submergence than under flooding. Thus, $P$. rigida is probably well adapted to survive in shallow flooding; nevertheless regimens of deep flooding and complete submergence for a longer period constitute a greater challenge, being a strong selective pressure for this species.

\section{Local adaptation to flooding}

In order to determine if there is genetic diversity between populations in molecular markers that could indicate the existence of different genotypes in the two populations, an AMOVA analysis was performed, resulting in a $\phi_{\text {st }}$ value of $6.27 \%$ (Table 3 ), indicating moderate genetic diversity between populations. This, together with the fact that some of the morphological and anatomical traits differed between populations (Table 2), allow us to presume that different genotypes constitute each population.

Parapiptadenia rigida saplings derived from the population historically challenged 
by flooding had higher means of the following root characters: thickness of the cortex, diameter of cortical cells and cortical porosity after experimental flooding; they also had a greater ability to resume growth after experimental submergence (Table 2). In order to understand this situation, the water levels of the Tibagi River basin must be considered. Trees of the population exposed to flooding are distributed very close to the river, where the soil is swampy most of the time. Along the year, a greater capacity to transport oxygen to the root system may be an important adaptation of this species to this riparian habitat. This would explain why characters related to aerenchyma formation have a better performance in trees from the population exposed to flooding. Around January, when the river overflows and young P. rigida saplings become completely submerged, their ability to restrain growth and to recover following the end of flooding may account for their success in this environment. Thus, the survival and anatomical variations observed in P. rigida populations indicate different levels of flooding tolerance and consequently ecotypic differentiation between the two habitats.

Local adaptation and ecotypic differentiation in plants related to flooding tolerance have rarely been reported. One of the few examples is a study on Himatanthus sucuuba (Ferreira et al., 2007; Parolin, 2009). In this species, seed viability, germination rates, overall survival of submerged seedlings, and the amount and pattern of aerenchyma formation differ significantly between populations from floodplain and upland environments. The differences in flooding tolerance within this species strongly indicate ecotypic differentiation between the two habitat types, suggesting that a process of separation into different species with differing waterlogging and submergence tolerance along the flooding gradient is occurring.

The $P$. rigida populations that we analyzed are distributed in a gradient of soil humidity of a riparian forest. Considering the relative proximity of the populations, the open pollination character of this species, and the high intrapopulational genetic diversity shown in AMOVA results (Table 3), genetic flow between them is likely. This indicates that evolution of flooding tolerance is not likely to be restricted by insufficient genetic variation in this species. Additional genetic variation could also be introduced in populations of river borders by the input of seeds from upstream regions through river flow.

Submergence is a strong selective pressure on P. rigida. Nonetheless, this species is able to recover from this stress, with a high rate of survival. This points to a potential application of $P$. rigida in reforestation programs in riparian ecosystems. The ability to survive prolonged flooding and submersion differed between the populations, even though the populations were close to each other and there was certainly gene flow. Plants from the area naturally exposed to flooding had a greater ability to recover after flooding followed by submergence, suggesting that these areas could be used as sources for seed for reforestation of riparian habitats.

\section{ACKNOWLEDGMENTS}

The authors thank CNPq for financial support.

\section{REFERENCES}

Bailey-Serres J and Voesenek LA (2008). Flooding stress: acclimations and genetic diversity. Annu. Rev. Plant Biol. 59: 313-339.

Batista CUN, Medri ME, Bianchini E, Medri C, et al. (2008). Tolerância à inundação de Cecropia pachystachya Trec. 
(Cecropiaceae): aspectos ecofisiológicos e morfoanatômicos. Acta Bot. Bras. 22: 91-98.

Chan JWY and Burton RS (1992). Variation in alcohol dehydrogenase activity and flood tolerance in white clover, Trifolium repens. Evolution 46: 721-734.

Coutts MP and Armstrong W (1976). Role of Oxygen Transport in the Tolerance of Trees to Waterlogging. In: Tree Physiology and Yield Improvement (Cannell MGR and Last FT, eds.). Academic Press, London, 361-385.

Davanso VM, Souza LA, Medri ME, Pimenta JA, et al. (2002). Photosynthesis, growth and development of Tabebuia avellanedae Lor. Ex Griseb. (Bignoniaceae) in flooded soil. Braz. Arch. Biol. Technol. 45: 375-384.

Davanso VM, Medri ME, Souza LA and Colli S (2003). Tabebuia avellanedae Lor. ex Griseb. (Bignoniaceae) submitted at the flooding and the "Ethrel" and silver nitrate application. Braz. Arch. Biol. Technol. 46: 57-64.

De Carvalho MCCG, Silva DCG, Ruas PM, Medri ME, et al. (2008). Flooding tolerance and genetic diversity in populations of Luehea divaricata. Biol. Plant. 52: 771-774.

Doyle JJ and Doyle JL (1987). A rapid DNA isolation procedure for small quantities of fresh leaf tissue. Phytotech. Bull. 19: 11-15.

Excoffier L, Smouse PE and Quattro JM (1992). Analysis of molecular variance inferred from metric distances among DNA haplotypes: application to human mitochondrial DNA restriction data. Genetics 131: 479-491.

Fernández MD (2006). Changes in photosynthesis and fluorescence in response to flooding in emerged and submerged leaves of Pouteria orinocoensis. Photosynthetica 44: 32-38.

Ferreira CS, Piedade MTF, Junk WJ and Parolin P (2007). Floodplain and upland populations of Amazonian Himatanthus sucuuba: effects of flooding on germination, seedling growth and mortality. Environ. Exp. Bot. 60: 477-483.

Huang B, Johnson JW, Box JE and NeSmith DS (1997). Root characteristics and hormone activity of wheat in response to hypoxia and ethylene. Crop Sci. 37: 812-818.

Huff DR, Peakall R and Smouse PE (1993). RAPD variation within and among natural populations of outcrossing buffalograss [Buchloë dactyloides (Nutt.) Engelm.]. Theor. Appl. Genet. 86: 927-934.

Kolb RM, Medri ME, Bianchini E and Pimenta JA (1998). Anatomia ecológica de Sebastiania commersoniana (Baillon) Smith \& Downs (Euphorbiaceae) submetida ao alagamento. Rev. Bras. Bot. [online] 21. [Doi: 10.1590/S0100$84041998000300010]$.

Kolb RM, Rawyler A and Braendle R (2002). Parameters affecting the early seedling development of four Neotropical trees under oxygen deprivation stress. Ann. Bot. 89: 551-558.

Kozlowski TT (1984). Responses of Woody Plants to Flooding. In: Flooding and Plant Growth (Kozlowski TT, ed.). Academic Press, London, 129-163.

Lenssen JPM, Kleunen MV, Fischer M and Kroon H (2004). Local adaptation of the clonal plant Ranunculus reptans to flooding along a small-scale gradient. J. Ecol. 92: 696-706.

Lopez OR and Kursar TA (1999). Flood tolerance of four tropical tree species. Tree Physiol. 19: 925-932.

Lopez OR and Kursar TA (2003). Does flood tolerance explain tree species distribution in tropical seasonally flooded habitats? Oecologia 136: 193-204.

Lorenzi H (1992). Árvores Brasileiras: Manual de identificação e Cultivo de Plantas Arbóreas Nativas do Brasil. Plantarum, Nova Odessa, 181.

Lynch M and Milligan BG (1994). Analysis of population genetic structure with RAPD markers. Mol. Ecol. 3: 91-99.

Mano Y, Omori F, Takamizo T, Kindiger B, et al. (2006). Variation for root aerenchyma formation in flooded and nonflooded maize and teosinte seedlings. Plant Soil 281: 269-279.

Medri ME, Bianchini E, Pimenta JA, Delgado MT, et al. (1998). Aspectos morfo-anatômicos e fisiológicos de Peltophorum dubium (Spr.) Taub. submetida ao alagamento e à aplicação de etrel. Rev. Bras. Bot. 21: 261-267.

Medri ME, Bianchini E, Pimenta JA, Colli S, et al. (2002). Studies on Flooding Tolerance in Native Tree Species From Tibagi River Basin. In: A Bacia do Rio Tibagi (Medri ME, Bianchini E, Shibatta OA and Pimenta JA, eds.). Universidade Estadual de Londrina, Londrina, 133-172.

Medri ME, Ferreira AC, Kolb RM, Bianchini E, et al. (2007). Morpho-anatomical alterations in plants of Lithraea molleoides (Vell.) Engl. submitted to flooding. Acta Sci. Biol. Sci. 29: 15-22.

Mielke MS, Almeida AA, Gomes FP, Mangabeira PAO, et al. (2005). Effects of soil flooding on leaf gas exchange and growth of two Neotropical pioneer tree species. New Forests 29: 161-168.

Parolin P (2002). Life history and environment of Cecropia latiloba in Amazonian floodplains. Rev. Biol. Trop. 50: $531-545$.

Parolin P (2009). Submerged in darkness: adaptations to prolonged submergence by woody species of the Amazonian floodplains. Ann. Bot. 103: 359-376.

Pimenta JA, Medri ME, Bianchini E, Müller C, et al. (1996). Aspectos da morfoanatomia e fisiologia de Jacaranda puberula Cham. (Bignoniaceae) em condições de hipoxia. Rev. Bras. Bot. 19: 215-220.

Pimenta JA, Bianchini E and Medri ME (1998). Adaptations to flooding by tropical trees: morphological and anatomical 
modifications. In: Ecophysiological strategies of xerophytic and amphibious plants in the Neotropics (Scarano FR and Franco AC, eds.). Universidade Federal do Rio de Janeiro, Rio de Janeiro, 157-176.

Pisicchio CM (2004). Respostas de Heliocarpus americanus L. (Tiliciaceae) ao Alagamento. Master's thesis, Universidade Estadual de Londrina, Londrina.

Santiago EF and Paoli AAS (2003). O aumento em superfície em Adelia membranifolia (Müll. Arg.) Pax \& K. Hoffm. e Peltophorum dubium (Spreng.) Taub., em resposta ao estresse por deficiência nutricional e alagamento do substrato. Rev. Bras. Bot. 26: 503-513.

Schmull M and Thomas FM (2000). Morphological and physiological reactions of young deciduous trees (Quercus robur L., Q. petraea [Matt.] Liebl., Fagus sylvatica L.) to waterlogging. Plant Soil 225: 227-242.

Schneider S, Kueffer JM, Roessli D and Excoffier L (1997). Arlequin Version 1.1: A Software for Population Genetic Data Analysis. University of Geneva, Geneva.

Silveira SR, Ruas PM, Ruas CF, Carvalho VP, et al. (2003). Assessment of genetic variability within and among coffee progenies and cultivars using RAPD markers. Gen. Mol. Biol. 26: 329-336.

Steege HT (1994). Flooding and drought tolerance in seeds and seedlings of two Mora species segregated along a soil hydrological gradient in the tropical rain forest of Guyana. Oecologia 100: 356-367.

Terazawa K and Kikuzawa K (1994). Effects of flooding on leaf dynamics and other seedling responses in flood-tolerant Alnus japonica and flood-intolerant Betula platyphylla var. japonica. Tree Physiol. 14: 251-261.

Tsukahara H and Kozlowski TT (1985). Importance of adventitious roots to growth of flooded Platanus occidentalis seedlings. Plant Soil 88: 123-132.

Yamamoto F (1992). Effects of depth of flooding on growth and anatomy of stems and knee roots of Taxodium distichum. Iawa Bull. 13: 93-104. 